\title{
Formulation and Evaluation of Antioxidant Peel-Off Mask Ethanol Extract Sarang Semut (Myrmecodia sp.) Using DPPH 2,2-Diphenyl-1- picrylhydrazyl Method
}

\author{
Nurista Dida Ayuningtyas ${ }^{1,{ }^{*}}$, Yahya Febrianto $^{1}$ and Alno Prasetyo ${ }^{1}$
}

\begin{abstract}
Background: Myrmecodia sp extract is known to be effective as an antioxidant on a concentration of 5-50 ppm. Antioxidants are substances that can scavenge free radicals. Free radicals can cause skin damage. Peel off mask is a cosmetic product that fungtion as a dead skin peel mechanically containing synthetic polymers that are quite safe and effective.

Aim: The purpose of this study was to determine the antioxidant effectiveness of the Myrmecodia sp extract. Method: The research used variations in the Myrmecodia sp extract of $2 \%, 3 \%$, and $4 \%$. The evaluation was carried out on the physical properties of the peel off mask and the antioxidant activity test. The antioxidant activity test used the 2,2-Diphenyl-1-picrylhydrazyl method. Statistical tests were carried out on the physical properties of the preparation and IC50 peel off mask using the one-way ANOVA test with a 95\% confidence level.

Result: Based on this research, it was found that the gel peel off mask preparation of Myrmecodia sp. extracts has organoleptic of a bit thick, brown and odorless. The value of adhesion is between 10.33-13.04 seconds, $\mathrm{pH}$ 6.27-6.75, viscosity 17.00-22.67 dPas, and drying time 17.33-24.33 minutes. The test for the antioxidant activity of IC50 peel off mask at F 2, F 3 and F 4 were $49.4 \mathrm{ppm}, 39.41 \mathrm{ppm}$ and $35.25 \mathrm{ppm}$ respectively.

Conclusion: The peel off gel mask of Myrmecodia sp. extracts has the potential as an antioxidant with the strong ability category.
\end{abstract}

Keywords: Myrmecodia sp, antioxidant, DPPH, Gel Peel off mask.

\section{BACKGROUD}

There are so many risk factors that cause premature aging besides free radicals itself, namely due to genetic factors, lifestyle, environment, gene mutations, and damage to the immune system ${ }^{1}$. Free radicals are molecules or atoms that are unstable because they have several unpaired electrons. These free radicals are very dangerous because they are very reactive to find their electronic partners ${ }^{2}$. Free radicals trigger problems that will arise, namely, the appearance of fine wrinkles, sagging skin muscles ${ }^{3}$, the appearance of black spots, the occurrence of an early and severe aging process can cause skin cancer. Examples of free radicals in everyday life such as cigarette smoke, motor vehicle fumes, use of drugs or chemicals that are consumed every day ${ }^{4}$.

${ }^{*}$ Correspondence: nuristad@gmail.com

${ }^{1}$ Nusaputera College of Pharmacy, Semarang, Indonesia

Full list of author information is available at the end of the article 
Free radicals can be inhibited by antioxidants. This is done by inhibiting the oxidation reaction caused by free radicals and will make it more stable ${ }^{5}$. Three species of sarang semut, namely Myrmecodia beccarii, Myrmecodia $s p$ and Hydnophytum sp, were tested for their antioxidant activity by the 2,2-Diphenyl-1picrylhydrazyl (DPPH) method. The results of the $\mathrm{IC}_{50}$ of each species were $8.18 \mathrm{ppm}, 21.79 \mathrm{ppm}$, and 25.31 ppm compared to vitamin $\mathrm{C}$ which had an $\mathrm{IC}_{50}$ value of $7.85 \mathrm{ppm}$. From this research, it can be seen that the ants have natural antioxidant activity ${ }^{6}$. In another study, the antioxidant activity of sarang semut was carried out with the Myrmecodia Tuburosa Jeck species from Central Sulawesi using the DPPH method at extract concentrations of 20,40, 60 and $80 \mathrm{ppm}$ showing $\mathrm{IC}_{50}$ activity of $26.84 \mathrm{ppm}$ which is classified as a very powerful antioxidant ${ }^{7}$.

Mask products that have been circulating in the community are powder masks, cream masks, gel mask, and paper mask. Types of masks that are practical to use are gel masks because after drying, it can be immediately exfoliated or commonly known as a peel off gel mask ${ }^{8}$. Sarang semut with Myrmecodia sp species to be used in this study as an active ingredient in the peel off gel mask preparation. Because it contains tannins, flavonoids, triterpenoids and tannins where these compounds can be thought to function as antioxidants ${ }^{6}$. Based on the anti-oxidant activity of the Myrmecodia sp. extracts, the researcher will make a peel off gel mask from the Myrmecodia sp. Evaluation of preparations includes the physical properties of the preparation (organoleptic, homogeneity, $\mathrm{pH}$, viscosity, adhesion, spreadability, and drying time) and test its antioxidant activity. Antioxidant activity was tested by the DPPH method. Compounds that react as free radical scavengers will reduce DPPH which can be observed with the DPPH color change from purple to yellow when the odd electron from the DPPH radical has paired with hydrogen from the free radical scavenger compound which will form reduced DPPH-H ${ }^{7}$.

\section{METHODS}

\section{Materials}

Sarang semut (Myrmecodia sp.), Vitamin C (Brataco), ethanol $70 \%$ (Brataco), carbomer (Brataco), aquadest (Brataco), polivinylalcohol (Brataco), triethanolamine (Brataco), glycerol (Brataco), methyl paraben (Brataco), phosphat dapar solution (Brataco), DPPH (Sigma Aldrich).

\section{Extract preparation}

Myrmecodia $s p$ was weighed 600 grams then extracted by maceration method using $70 \%$ alcohol as much as $4 \mathrm{~L}$ for 3 days. The extraction results are evaporated using a rotary evaporator, so that a thick extract is obtained 7 .

\section{Formulation and Physical Properties Test of Myrmecodia sp.Extract Gel Peel Off Mask}

The manufacturing procedure was developed for PVA in hot aquadest at $80^{\circ} \mathrm{C}$ until it fully expanded, then stirred. Also developed is the carbomer in cold aquadest for one day until it fully expands. Then, added glycerin, methyl paraben which has been dissolved in hot aquadestilata, carbomer, and TEA respectively into the PVA mass, stirring until homogeneous. After that, add the extract which has been previously dissolved in aquadestilata little by little, then stirring until homogeneous. Physical properties test of Myrmecodia sp. extract gel peel off mask preparation included organoleptic, homogeneity, $\mathrm{pH}$, viscosity, adhesion, and drying time ${ }^{8}$. 
Table 1. Formula Gel Peel Mask Off Myrmecodia $s p$

\begin{tabular}{ccccc}
\hline Ingredient & F1 & F2 & F3 & F4 \\
\hline Extract Myrmecodia & - & $2 \%$ & $3 \%$ & $4 \%$ \\
$s p$ & & & & \\
Carbomer & $10 \%$ & $10 \%$ & $10 \%$ & $10 \%$ \\
PVA & $4 \%$ & $4 \%$ & $4 \%$ & $4 \%$ \\
TEA & $2 \%$ & $2 \%$ & $2 \%$ & $2 \%$ \\
Glycerol & $10 \%$ & $10 \%$ & $10 \%$ & $10 \%$ \\
Metyhl paraben & $0,2 \%$ & $0,2 \%$ & $0,2 \%$ & $0,2 \%$ \\
Aquadest & ad 30 g & ad 30 g & ad 30 g & ad 30 g \\
\hline
\end{tabular}

\section{Evaluation the physical characteristics of the peel off gel mask Organoleptic}

The shape, color and smell of mask preparations were observed ${ }^{9}$.

\section{Homogenity test}

0.1 gram of mask preparation is weighed then smeared on a transparent glass plate and visually see if there are any parts that are not mixed properly ${ }^{9}$.

pH test

Take enough mask preparations and measure the $\mathrm{pH}$ with a $\mathrm{pH}$ stick. The $\mathrm{pH}$ of the mask must be in accordance with the $\mathrm{pH}$ of the skin, namely $4.5-6.5^{9}$.

\section{Viscosity}

The mask viscosity test is intended for now the thickness of each makser. Test this is done using a portable device the rion viscotester by placing the mask in the cup and turning the rotor on ${ }^{10}$.

\section{Adhesion test}

The adhesion test is done in a way weigh 1 gram of mask that is put on one of the surface of the slide is then closed with another object glass. The object glass is crushed with a load of $1 \mathrm{~kg}$ for 5 minutes. Object glass which coincide then mounted on the test equipment adhesion and simultaneously with the loading on the adhesion power tester, the stopwatch is switched on ${ }^{10}$.

\section{Drying time test}

0.3 gram of mask preparation applied to the skin surface with a size of $3 \mathrm{~cm} \times 3 \mathrm{~cm}$. Let stand until dry and note the time the preparation dries. Preparations are said to dry out when they can be removed / withdrawn easily ${ }^{9}$.

\section{Antioxidant Activity Test of Peel Off Mask Myrmecodia sp. Extract}

The sample of 5 grams was taken and then extracted with the addition of ad. $50 \mathrm{ml}$ of $70 \%$ alcohol, shake quickly for about 5 minutes. Then the shaking results are filtered and the filtrate is accommodated. Dilution was carried out with a standard series of 10, 20, 30, 40, and $50 \mathrm{ppm}$. Furthermore, $10 \mathrm{~mL}$ of each sample solution were added with $2 \mathrm{~mL}$ of DPPH. The test solution and blank solution were incubated at temperature for 30 minutes. For the activity test of comparative preparations of vitamin $\mathrm{C}$ were treated the same ${ }^{11}$. The uptake of the test solution was measured by a UV-Vis spectrophotometer at the maximum wavelength. \% inhibition can be calculated using the formula:

$$
\text { \%inhibition }=(\text { abs. control }- \text { abs. sample }) / \text { abs. control } \times 100 \%
$$




\section{RESULTS}

The extract of the Myrmecodia sp. extract obtained by the extraction process is brownish in color, slightly thick liquid and has a distinctive smell. The yield of the extract obtained was $1.573 \%$. The extract is then used to make a peel off gel mask according to the formula and to test its antioxidant activity with DPPH.

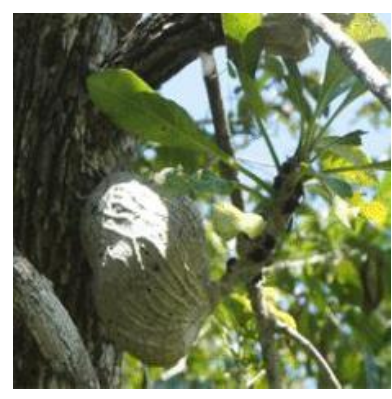

(a)

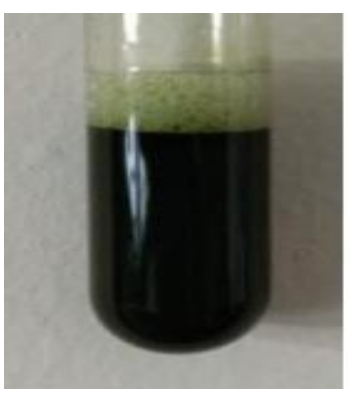

(b)

Figure 1. Plant results of origin Myrmecoadia sp and (b) extract

The results of the organoleptic test and homogeneity of the base formula were white, odorless, thick and homogeneous. The formula of the Myrmecodia sp. extract is brown, odorless, with a thick and homogeneous form.

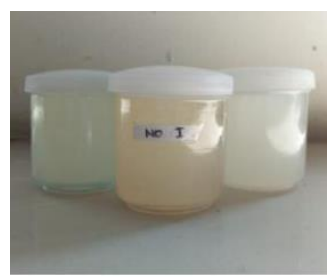

Formula 1

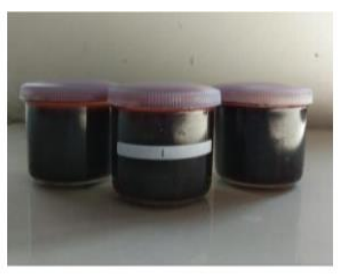

Formula 2

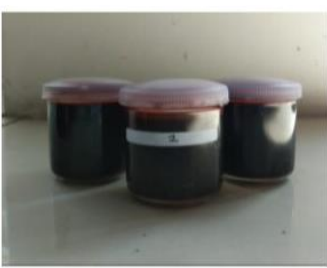

Formula 3

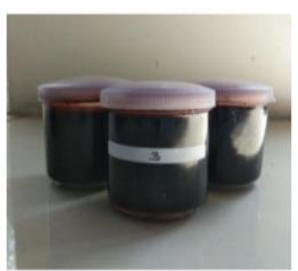

Formula 4

Figure 2. Gel peel off mask Myrmecodia sp extract

In the adhesion test, $\mathrm{pH}$, viscosity and drying time of the base formula and the sample containing the extract, the results obtained in Table 2

Table 2. Physical Properties Gel Peel Off Mask

\begin{tabular}{lllll}
\hline \multicolumn{1}{c}{ Sampel } & Adhesion (detik) & pH & Viscosity (dPas) & Drying time (menit) \\
\hline F 1 (Basis) & $10.33 \pm 0.6361$ & $6.75 \pm 0.0306$ & $22.67 \pm 2.5166$ & $17.33 \pm 1.5275$ \\
F 2 & $11.60 \pm 0.7702$ & $6.481 \pm 0.02$ & $21.67 \pm 2.0817$ & $19.33 \pm 1.5275$ \\
F 3 & $12.28 \pm 0.1652$ & $6.34 \pm 0.0777$ & $17.00 \pm 2.00$ & $22.67 \pm 1.5275$ \\
F 4 & $13.04 \pm 0.2157$ & $6.27 \pm 0.03$ & $21.33 \pm 2.5166$ & $24.33 \pm 2.0187$ \\
\hline
\end{tabular}

The antioxidant activity test of the peel off mask aims to see how much the peel off mask can counteract free radicals. From the test results obtained results like the figure 2. 


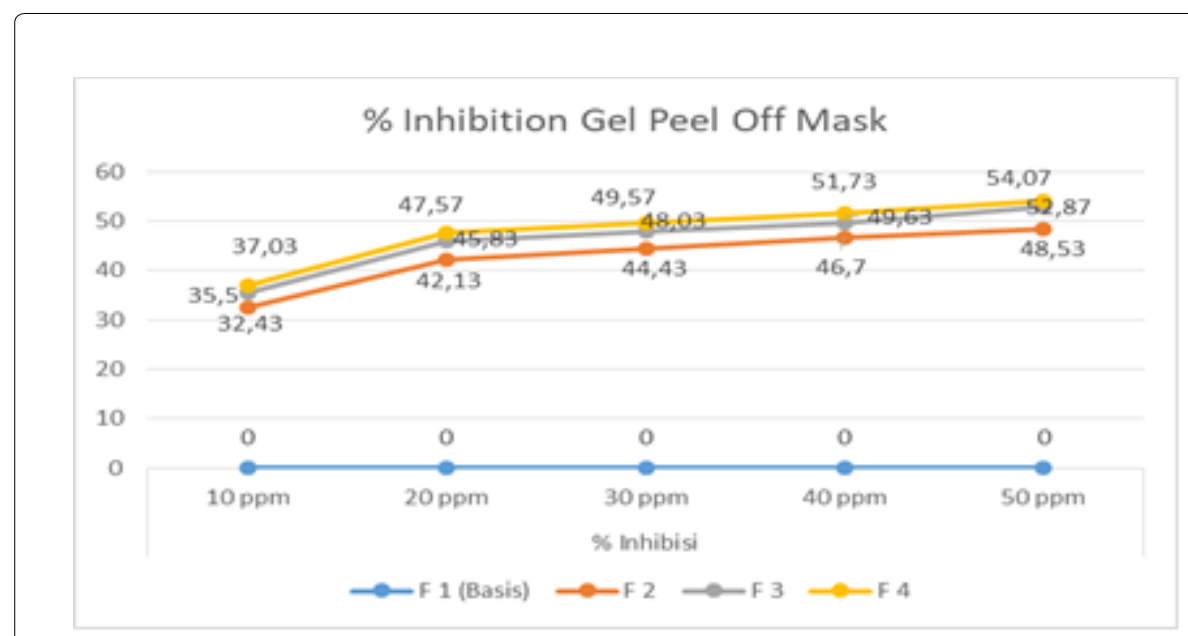

Figure 3. \% Inhibition Gel Peel Off Mask Myrmecodia sp. Extract

From the \% inhibition value, a plot was made to look for the linear regression equation obtained from measuring the antioxidant activity of the peel off gel mask. The regression equation is calculated to get the $\mathrm{IC}_{50}$ value. The results of the $\mathrm{IC}_{50}$ value can be seen in Figure 3.

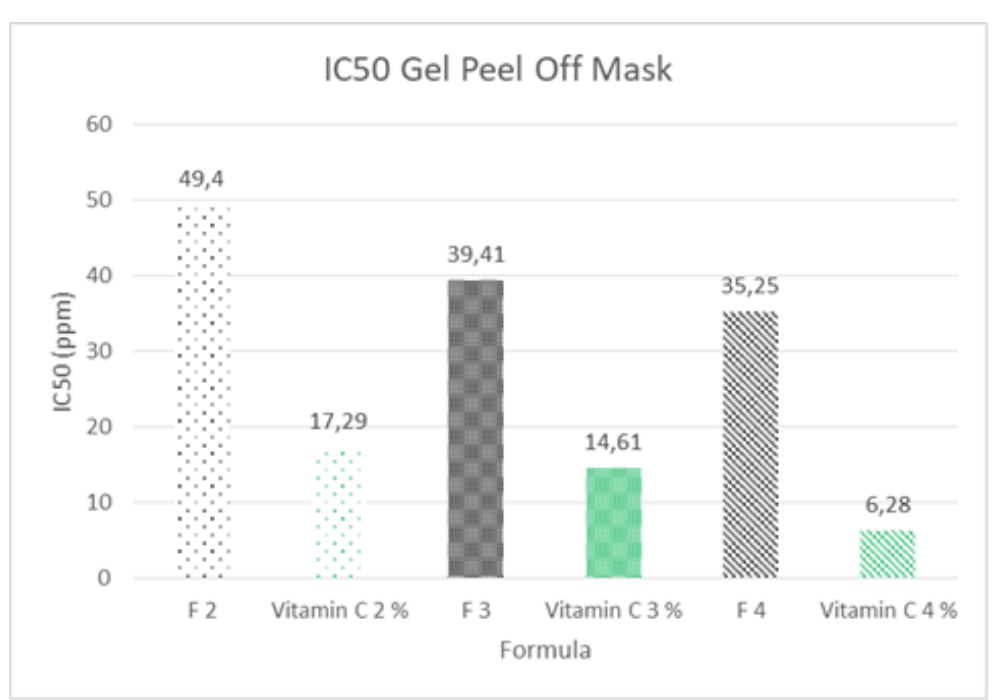

Figure 4. IC50 gel peel off mask

Based on these data, it is known that the Myrmecodia sp. extracts has a strong ability to inhibit free radical compounds, while vitamin $\mathrm{C}$ has a better ability, namely strong to very strong in inhibiting free radicals.

\section{DISCUSSION}

Myrmecodia sp. extract is made in a peel off gel mask preparation because it has the advantage that it can be easily removed or lifted like an elastic membrane and increases hydration of the skin. In the formulation, a combination of PVA and Carbomer is used as a gelling agent. Gelling agents are made with variations in levels 
$0,2,3$, and $4 \%$. Variation in levels was made with the aim of knowing the difference in antioxidant activity of each formula. Carbopol was chosen as a gelling agent because it has good spreadability on the skin, has a cooling effect, does not clog skin pores and is easily washed with water. Carbopol has a pH of 2.5-3.5 so a substance used to increase the $\mathrm{pH}$ is needed, namely Triethanolamine. TEA is used as an alkalizing agent which can increase the $\mathrm{pH}$ of the preparation and also increase the viscosity of the preparation ${ }^{12}$. From the results obtained, the peel of mask has the same form because it uses the same formula, smells of PVA because it is not given essens and the maximum concentration of PVA results in the dominant smell of PVA. The different colors on each preparation were obtained from the color of the active substance.

The adhesion test aims to determine the ability of the gel peel off mask preparation of Myrmecodia sp extract to adhere to the skin after application to function optimally. From the test results, it is known that the adhesion range is 10.33-13.04 seconds. The adhesion requirement for the preparation is 2-300 seconds ${ }^{13}$. So it can be concluded that the formula has met the requirements. F 4 has a stronger adhesion than other formulas, the strong adhesion can cause the active substance to stick to the skin surface for a long time ${ }^{10}$. The results of the test for the adhesion of the peel off mask of the Myrmecodia sp. extracts were carried out by the one-way ANOVA test, the $\mathrm{p}$ value was $0.96<0.05$, which means that there is a significant difference between each formula.

$\mathrm{pH}$ test is performed to determine the $\mathrm{pH}$ of the gel preparation and so as not to irritate the skin. From the results of $\mathrm{pH}$ testing, it is known that the high concentration of peel off mask does not affect the $\mathrm{pH}$ of the preparation. The $\mathrm{pH}$ test results for the peel off mask for Myrmecodia sp extract ranged from 7.57 to 7.74. The $\mathrm{pH}$ requirement of the preparation is in accordance with the $\mathrm{pH}$ of the skin (4.5 - 6.5). The test results are not in accordance with the $\mathrm{pH}$ requirements of the skin because there are additional TEA ingredients in the formula which are weakly alkaline causing the $\mathrm{pH}$ to rise to neutral. But these results are still acceptable because if the results are too acidic it can cause irritation to the skin, whereas in preparations that are formed the ph tends to be alkaline, the effect that is caused can cause the skin to become dry ${ }^{14}$. The results of the $\mathrm{pH}$ test for the preparation of the peel off mask for the Myrmecodia sp extract were subjected to a one-way ANOVA statistical test. The one-way ANOVA test results obtained $p$ value $0.54<0.05$, which means that there is no significant difference in each formula.

The viscosity test aims to determine the consistency of the peel off mask preparation. The viscosity of the peel off mask dosage greatly affects the ease of pouring the preparation when it is to be used. Because the liquid texture of the extract causes more extract to be used, the viscosity of the preparation will be lower and the peel off mask will be easier to pour. In the statistical test with one-way ANOVA, the p value was 0.31 $<0.05$, so it could be interpreted that there was a significant difference in each formula.

The drying time test aims to determine the length of time it takes for the peel off preparation from when it is used on facial skin until it is dry and can be exfoliated. From the results obtained, it is known that the greater the extract concentration, the greater the time required for drying. This is also influenced by the high concentration of PVA where PVA has hydrophilic properties which cause the preparation to easily attract moisture from the air. The results of the drying time for the peel off gel extract mask were between 17.3324.33 minutes. The presence of a high enough extract content in F 4 resulted in the preparation drying longer. In the statistical test with one-way ANOVA, the $\mathrm{p}$ value was $0.00<0.05$, which means that there are significant differences in each formula.

On antioxidant activity test using the DPPH method, the $\mathrm{IC}_{50}$ Vitamin $\mathrm{C}$ has a better ability to inhibit free radicals. This is because vitamin $\mathrm{C}$ is a water-soluble antioxidant and has reducing properties. This reducing property is caused by the easy release of the hydrogen atom in the hydroxyl group so that it is bonded to the $\mathrm{C}_{2}$ and $\mathrm{C}_{3}$ atoms ( $\mathrm{C}$ atoms with a round bond) so that the radicals are easy to catch which form stable reduction free radicals ${ }^{15}$. The presence of a DPPH compound which is a free radical when added to a sample that can donate a hydrogen atom, the DPPH compound will become its reduced form which is marked by a color change from bronze to yellow. In the sample, the Myrmecodia sp. contains flavonoids which can donate a hydrogen atom so that it reacts to the DPPH radical and stabilizes the radical electron ${ }^{7}$. The results of the antioxidant test for gel mask peel off extract followed by one-way ANOVA statistical test and obtained a $p$ value of $0.00<0.05$, which means that there is a significant difference between each formula. 


\section{CONCLUSION}

Based on the research results, Formula 4 is the best formula because it can provide great adhesion to the skin surface and has the greatest IC50 value, namely $35.25 \mathrm{ppm}$. Further research that can be done is in vivo advanced antioxidant activity tests.

\section{ACKNOWLEDGEMENT}

Thanks to the research team who have carried out the research process up to publication. Nusaputera College of Pharmacy which facilitates and allows researchers to conduct research in the Pharmaceutical Technology Laboratory.

\section{CONFLICT OF INTEREST}

Researchers do not experience conflicts of interest with all research teams or with the authors referred to for the preparation of the publication manuscript.

\section{AUTHORS' CONTRIBUTION}

AP was in charge of collecting data on antioxidant activity. YF is in charge of making the peel off gel mask formula. ND is in charge of drafting proposals, final reports and research publications.

\section{FUNDING}

None

\section{AUTHOR DETAILS}

${ }^{1}$ Nusaputera College of Pharmacy, Semarang, Indonesia

\section{REFERENCES}

1. Irawati L, Sulandjari S. Pengaruh Komposisi Masker Kulit Buah Manggis (Garcinia Mangostana L) Dan Pati Bengkuang Terhadap Hasil Penyembuhan Jerawat Pada Kulit Wajah Berminyak. E-Journal. 2013;02(02):40-48.

2. Siswono Handoko Jati. SALAM ( Syzygium polyanthum [ Wight .] Walp . ) PADA HATI SISWONO HANDOKO JATI FAKULTAS FARMASI. Published online 2008.

3. Atmaja NS, Marwiyah, Setyowati E. Pengaruh Kosmetika Anti Aging Wajah Terhadap Hasil Perawatan Kulit Wajah. J Beauty Beauty Heal Educ. 2012;1(1):1-7.

4. angela Lasmida F. Aktivitas Antioksidan dan Stabilitas Fisik Gel anti-aging yang Mengandung Ekstrak Air Kentang Kuning. Univ Indones. Published online 2012.

5. Fitriana WD, Fatmawati S, Ersam T. Uji Aktivitas Antioksidan terhadap DPPH dan ABTS dari Fraksifraksi. SNIP Bandung. 2015;2015(Snips):658.

6. Dirgantara S, Nawawi ASARI, Insanu DANM. Uji Aktivitas Antioksidan Tiga Spesies Tanaman Sarang Semut ( Famili : Rubiaceae ) Asal Kabupaten Merauke , Papua. 2013;5(April):10-14.

7. Pande Indra, Supriadi I. Uji Aktivitas Antioksidan Ekstrak Tumbuhan Sarang Semut (Myrmecodia Tuberosa Jeck) Asal Kabupaten Toli-Toli Sulawesi Tengah. J Akad Kim. 2019;8(2):98-103. doi:10.22487/j24775185.2019.v8.i2.2754

8. Muflihunna A, Mursyid, Mumtihanah A. FORMULASI DAN EVALUASI MASKER GEL PEEL-OFF EKSTRAK ETANOL KULIT BUAH APEL ( Phyrus mallus L ) SEBAGAI ANTIOKSIDAN penuaan . Salah satu sediaan kosmetik untuk menjaha kebersihan dan perawatan kulit wajah off ( Muliyawan 2013 ). Oleh karena itu dikembangkan. J Kesehat. 2019;(November):35-44. 
doi:10.24252/kesehatan.v0i0.11355

9. Jani TA, Hakim A, Juliantoni Y. Formulation and Evaluation of Antioxidant Peel-Off Face Mask Containing Red Dragon Fruit Rind Extract (Hylocereus polyrhizus Haw.). J Biol Trop. 2020;20(3):438. doi:10.29303/jbt.v20i3.2157

10. Prasetyo TTB. Formulasi Salep Ekstrak Etanolik Daun Binahong (Anredera cordifolia (Ten.) Steenis) dengan Berbagai Basis dan Uji Aktivitas. J Farm. 2015;1(1):41-48.

11. Murti RW, Praditia NA, Hadifa HU, Naqi F, Wijayanti R. Aktivitas Antioksidan dan Uji Iritasi Sediaan Masker Gell Peel-Off Ekstrak Metanol Kulit Buah Rambutan (Nephelium Lappaceum L.). J Ilmu Farm dan Farm Klin. 2016;13(2):32-38.

12. Raymon C Rowe, Paul J Sheskey MEQ. Handbook Of Pharmaceutical Excipient. VI. Pharmaceutical Press; 2009.

13. Betageri G; Prabu S. No TitleEncyclopedia of Pharmaceutical Technology. 2 nd. Macel Dakker Inc; 2002.

14. Barry W. Dermatological Formulations Percutaneous Absorbtion. Marcel Dekker Inc; 1983.

15. Setiyaningrum Z. AKTIVITAS ANTIRADIKAL DPPH DAN KADAR FENOLIK DARI EKSTRAK GAMBIR ( Uncaria gambir Roxb ) MENGGUNAKAN METODE MASERASI DAN SOXHLET. Published online 2013. 